\title{
POTENTIAL FEEDBACKS BETWEEN PACIFIC OCEAN ECOSYSTEMS AND INTERDECADAL CLIMATE VARIATIONS
}

by Arthur J. Miller, Michael A. Alexander, George J. Boer, Fel Chal, Ken Denman, David J. Erickson III, Robert Frouin, Albert J. Gabric, Edward A. Laws, Marlon R. Lewis, Zhengyu liu, Ragu Murtugudde, Shoichiro Nakamoto, Douglas J. Neilson, Joel R. Norris, J. Carter Ohlmann, R. Ian Perry, Niklas Schneider, Karen M. Shell, and Axel TimmermanN

Oceanic ecosystems altered by interdecadal climate variability may provide a feedback to the physical climate by phytoplankton affecting heat fluxes into the upper ocean and dimethylsulfide fluxes into the atmosphere.

0 ceanic ecosystems influence climate on many time and space scales. But this influence is not well understood. It is clear that interdecadal ${ }^{1}$ physical climate variations occur in the Pacific sector. Interdecadal sea surface temperature (SST) anoma-

\footnotetext{
${ }^{1}$ We use the term "interdecadal" to loosely refer to timescales that are longer than interannual (ENSO) and shorter than centennial (greenhouse gas forcing).
}

lies show a "canonical" structure (e.g., Tanimoto et al. 1993; Zhang et al. 1997), with central North Pacific SSTs near the subtropical front bracketed to the east, north, and south by oppositely signed SSTs. A second SST pattern is centered around the subpolar front in the Kuroshio-Oyashio Extension region (Deser and Blackmon 1995; Nakamura et al. 1997) and tends to lag the subpolar front SST anomalies by a few years on interdecadal timescales (Miller and Schneider
AFFILIATIONS: Miller, Frouin, NeILSON, NoRris, SCHNeider, AND SHELL-Scripps Institution of Oceanography, University of California, San Diego, La Jolla, California; AleXANDER-NOAA/Climate Diagnostics Center, Boulder, Colorado; Boer and DenmanMeteorological Service of Canada, University of Victoria, Victoria, British Columbia, Canada; CHAl—University of Maine, Orono, Maine; ERICKSON-Oak Ridge National Laboratory, Oak Ridge, Tennessee; GABRIC - Griffith University, Nathan, Australia; LAws-University of Hawaii at Manoa, Honolulu, Hawaii; LewIs—Dalhousie University, Halifax, Nova Scotia, Canada; LıU-University of WisconsinMadison, Madison, Wisconsin; MURTUGUdDE-University of Maryland, College Park, College Park, Maryland; NaKamoto—Advanced Earth
Science and Technology Organization, Tokyo, Japan; OHLMANNUniversity of California, Santa Barbara, Santa Barbara, California; Perry-Fisheries and Oceans Canada, Nanaimo, British Columbia, Canada; TIMMERMANN-Institut für Meereskunde, Kiel, Germany CORRESPONDING AUTHOR: Dr. Arthur J. Miller, Climate Research Division, Scripps Institution of Oceanography, University of California, San Diego, La Jolla, CA 92093-0224

E-mail: ajmiller@ucsd.edu DOI: 10.1 I75/BAMS-84-5-6I7

In final form 14 October 2002 (C) 2003 American Meteorological Society 
2000). The North Pacific thermocline observations show interdecadal structures linked to wind stress curl forcing (Miller et al. 1998; Tourre et al. 1999) and to anomalous subduction from buoyancy forcing (Deser et al. 1996; Schneider et al. 1999). These observed patterns may indicate preferred natural modes of variability in the climate system or may be simply a passive response to the long-period atmospheric forcings.

The mechanisms responsible for interdecadal climate variability in the Pacific, however, are not very clear. A number of possible physical feedback loops (i.e., coupled oscillations) in the ocean-atmosphere system have been proposed to explain aspects of observed and modeled climate variations (e.g., Latif 1998; Miller and Schneider 2000). However, interdecadal feedback mechanisms cannot be unambiguously identified in existing observations and they are not robust in the coupled general circulation models (CGCMs) whose results have been analyzed. Moreover, stochastic driving of the ocean by the atmosphere can potentially account for a considerable portion of observed and modeled interdecadal variability (Barsugli and Battisti 1998; Frankignoul et al. 1997) with or without feedbacks.

While physical-biological feedbacks may only account for a small fraction of the observed interdecadal climate variability, it is nevertheless of interest to ask if these exist and are of potential importance. We therefore attempt to answer a sequence of questions:

- What mechanisms might allow Pacific Ocean biological responses to influence variations of the physical climate system on interdecadal timescales?

- Do these oceanic biological feedback mechanisms increase or decrease the Pacific Ocean-atmosphere sensitivity to physical climate interactions?

- In what key regions of the Pacific Ocean might these biological influences be active?

- How can these possible biological feedbacks be tested with models and observations?

The goal of this paper is to motivate a coordinated modeling and observational effort to study coupled physical-biological mechanisms of interdecadal climate variability in the Pacific. (This discussion frequently applies as well to climate processes with interannual and centennial timescales.)

HEURISTIC PERSPECTIVE OF BIOLOGY AND CLIMATE. Our current description of the climate system is usually based on a somewhat artificial separation into an external and an internal com- ponent. This separation is clear in the case of modern climate models where the external system is specified in the model code (e.g., the shape, size, geography, and rotation rate of the earth; the composition of the atmosphere; etc.) Given this external information, the internal component prognostic variables such as temperatures, winds, precipitation rates, etc., are generated with the governing equations as the model is integrated in time. Biological processes are not part of the internal system of current global coupled climate models used that are externally forced (e.g., Table 9.1, chapter 9 in Houghton et al. 2001). Biological processes are lacking as part of the external system of these models as well (except perhaps as specified features of the land surface such as the roughness and albedo associated with differing vegetation cover). For the oceans, current CGCMs typically do not include biological processes as part of either the internal or external system.

This situation, however, is rapidly changing and simplified representations of some oceanic and terrestrial biology, particularly as they affect the carbon budget and radiation balances, are beginning to appear in coupled model simulations (e.g., MaierReimer et al. 1996; Sarmiento et al. 1998; Matear and Hirst 1999; Cox et al. 2000). This is a necessary trend. Biology can affect climate by modifying the earth's energy budget, by changing the transparency or reflectivity of the system via aerosols and cloud effects, or by modifying the surface albedo or absorptivity of the ocean. The longwave energy output may be modified via the greenhouse gas concentration of the atmosphere and/or cloud processes. The search for important biological climate processes must also consider the response of the climate system. A locally strong, biologically mediated perturbation to the flow of energy may only produce a locally weak and globally trivial effect, because the climate system rapidly distributes and dilutes local perturbations via the atmosphere. [See Denman et al. (1996) for a review of the main mechanisms by which marine ecosystems might respond and feed back to a changing climate.]

Physical processes of Pacific interdecadal variability. There are many ideas about how feedback mechanisms in the physical climate system may control the portion of Pacific interdecadal climate variations that are not simply explained by stochastic theories [e.g., Miller and Schneider (2000) summarize these]. Many propose a delay mechanism to explain observations.

One of the prominent theories to explain Pacific interdecadal climate variations is the subduction mode hypothesis (Gu and Philander 1997; Fig. 1). 
Temperature anomalies generated in the central North Pacific are subducted and move toward the equator along typical pathways of thermocline waters. The anomalies arrive in the tropical Pacific after one to several decades. There, air-sea interactions are hypothesized to amplify the exhausted temperature anomalies. A warm equatorial SST anomaly strengthens the atmospheric Hadley circulation and, in turn, the midlatitude westerly wind. The stronger surface westerly cools the midlatitude SST. In this way, temperature anomalies of the reversed sign could be generated within the central North Pacific, initiating the other half of the cycle.

This proposed mechanism, if it works in reality, does not appear to be very efficient. Subducted temperature anomalies can be traced along their southward route to subtropical latitudes but not farther (Schneider et al. 1999). Another complication is that temperature anomalies are not passive tracers, since they modify the subsurface density. This in turn can generate waves (Liu and Shin 1999) that can alter the tropical circulation. The sensitivity of atmospheric circulation to SST anomalies and ocean heat transport (Wang and Weisberg 1998) may also influence this mechanism.

Another influential theory of Pacific interdecadal climate variations is the midlatitude gyre mode hypothesis (Latif and Barnett 1994; Fig. 1). The basic idea is as follows: a warm SST anomaly in the western-central extratropical Pacific is argued to modify the atmospheric circulation. Atmospheric feedback enhances the local SST anomaly, but also a wind stress curl anomaly in the central-eastern extratropical $\mathrm{Pa}$ cific triggers westward-propagating upwelling Rossby waves. It is argued that this adjusts the circulation of the subtropical gyre after many years. The associated changes in the western boundary currents then reverse the original SST anomalies and commence the oppositely signed patterns. Typical timescales for this type of coupled air-sea mode are between 10 and $20 \mathrm{yr}$.

The full-physics coupled models to date have not generated either of these two broad categories of feedback loops (Schneider et al. 1999, 2002). The hints of ocean-atmosphere feedbacks that have been detected do not seem to be consistent with the two leading hypotheses (at least for the Pacific Ocean). Instead, stochastic forcing of the ocean by the atmosphere can explain the bulk of interdecadal Pacific climate variability found in full-physics models.

Other physical processes may contribute to the enhanced variance associated with stochastic processes at interdecadal timescales. The "reemergence mechanism" allows thermal anomalies created in the deep winter mixed layer to be stored in the summer

\section{Subduction Mode}

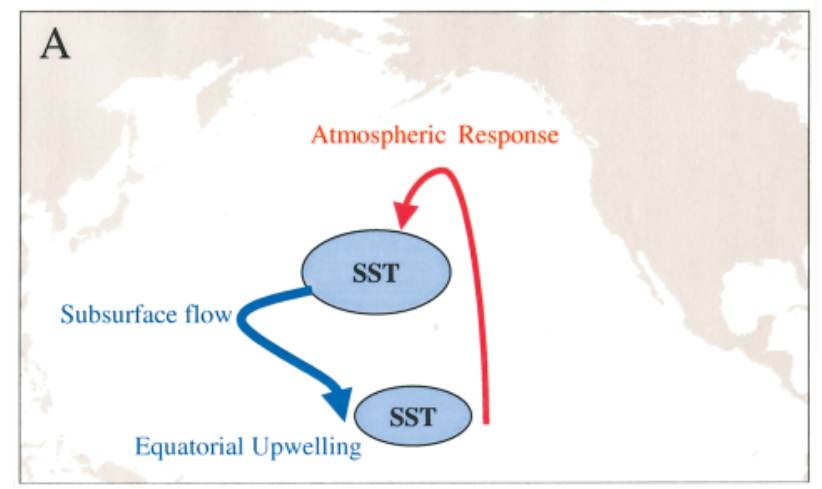

\section{Midlatitude Gyre Mode}

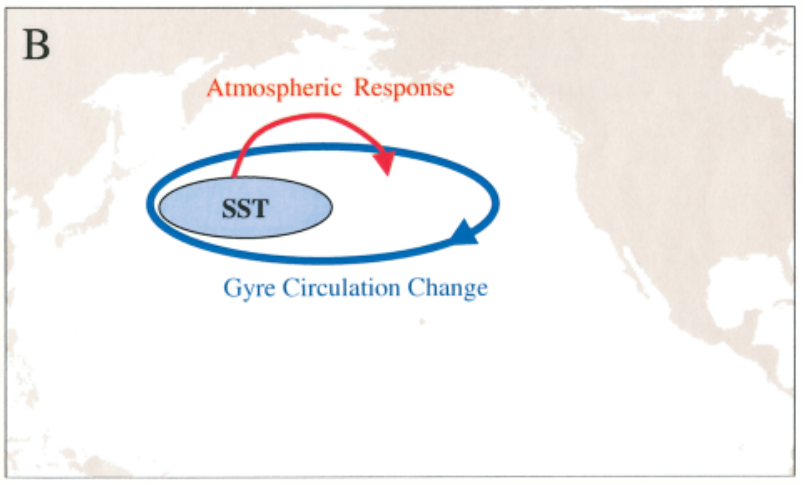

Fig. I. Sketch of basic processes involved in the subduction mode and midlatitude gyre mode that have been proposed to explain interdecadal variability in the Pacific. The subduction mode involves a midlatitude SST anomaly that subducts into the thermocline and upwells in the Tropics after a delay to drive the atmospheric bridge, which forces a midlatitude SST anomaly of opposite polarity. The midlatitude gyre mode involves the atmosphere responding to SST, which is driven by a delayed response of the midlatitude gyre current system to antecedent atmospheric forcing with opposite polarity.

seasonal thermocline (where they are insulated from surface fluxes) and then remixed in the surface layer the following fall and winter. Reemergence has been documented over much of the North Atlantic and Pacific (Alexander et al. 1999, 2001). This mechanism can maintain SST anomalies and their influence on the atmosphere for several years in regions of deep winter mixed layers (Alexander et al. 2000; Watanabe and Kimoto 2000).

Interdecadal climate variations may result from the slow adjustment of the speed of the shallow vertical overturning cell between the Tropics and extratropics (Kleeman et al. 1999). The speed of equatorward flow in the Pacific thermocline and poleward return flow 
Interdecadal variations of biological systems in the Pacific Ocean appear to be linked to climate variability (Francis et al. 1998). In some cases, like the anchovy and sardine regimes that last $10-50$ yr (e.g., Baumgartner et al. 1992; Ware 1995; Schwartzlose et al. 1999; Field and Baumgartner 2000), most of the variance is interdecadal.

Many population variations have been linked to specific physical changes. Biological change is often linked to SST change, but, since SST is often correlated with other physical changes (such as upwelling, mixing, and horizontal currents), the specific mechanisms linking physical and ocean ecosystem changes have remained difficult to isolate. For example, Whitney et al. (1998) have documented a dramatic decline in nitrate (an essential nutrient for phytoplankton) in the northeast Pacific that may be related to declining wind stress curl and shoaling of the ocean mixed layer. A shoaling mixed layer and warmer upperlayer temperatures are also implicated in significant changes in the life cycle timing of the major copepod species in the northeast Pacific (Mackas et al. 1998), which, in turn, might influence fish production.

Interdecadal variations in oceanic physical variables have many implications for marine ecosystems (Mantua et al. 1997; Sugimoto and Tadoroko 1997; McGowan et al. 1998). Widespread ecological changes associated with the 1976-77 climate shift (Miller et al. 1994) were observed throughout the North Pacific Ocean, ranging from plankton to high trophic level changes (Venrick et al. 1987; Polovina et al. 1994; Francis and Hare 1994). In the northwestern subtropical gyre, chlorophyll in spring increased steadily from the mid-1970s to the mid-1980s (Limsakul et al. 200I). Around
1976-77, the small pelagic fish stocks off the coast of Peru shifted from anchovy to sardine dominance (Schwartzlose et al. 1999). While there are no data to confirm this, modeling studies indicate that the tropical nutricline also shifted during 197677 along with the thermocline shift that was noted in coral records (Guilderson and Schrag 1998). It is thus likely that the primary producers in the Tropics also experienced an interdecadal shift. The feedback between this ecosystem shift and the physical dynamics and thermodynamics needs to be assessed in the context of frequency and amplitude changes of ENSO (Trenberth and Hoar 1996).

To model springtime (MarchApril) phytoplankton in the northwest Pacific before and after the 1976-77 climate shift, Chai et al. (2002b, manuscript submitted to $\mathrm{J}$. Oceanogr., hereafter CJBDC) have incorporated an

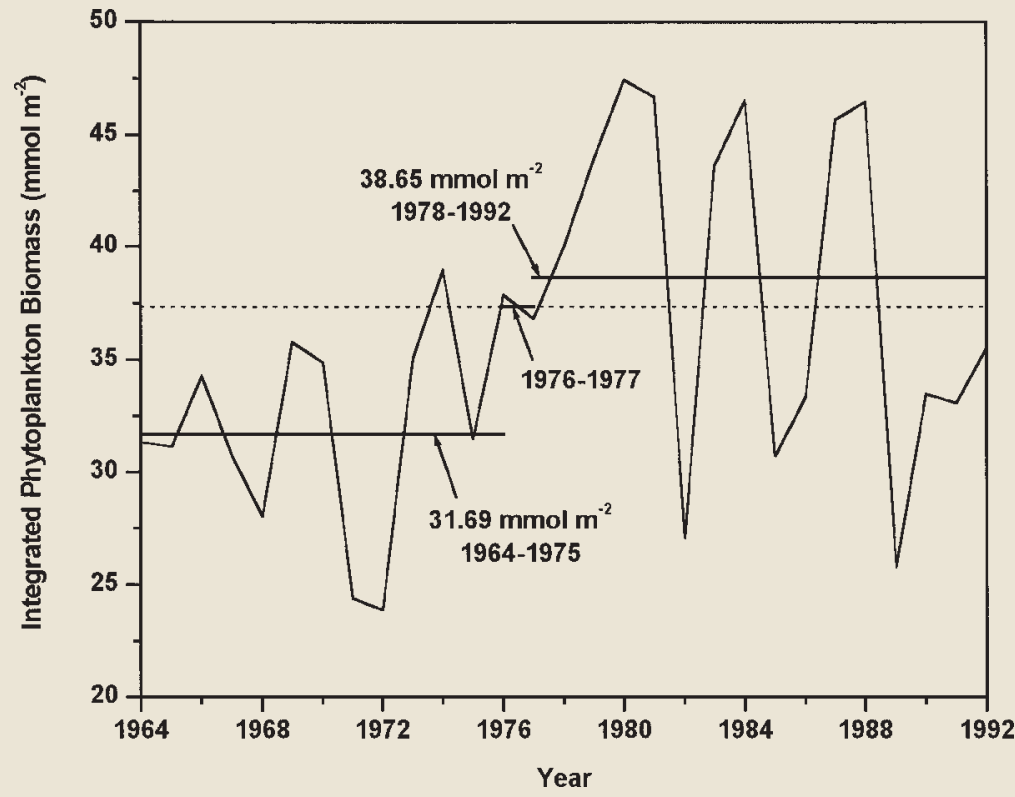

FIG. SB I. Modeled ecosystem response to the 1976-77 climate shift physical forcing (from CJBDC). The springtime (Mar-Apr), vertically integrated $(0-100 \mathrm{~m})$ phytoplankton (quantified as $\mathrm{mmol}$ of nitrogen) for the northwest Pacific $\left(35^{\circ}-45^{\circ} \mathrm{N}\right.$, $\left.160^{\circ} \mathrm{E}-160^{\circ} \mathrm{W}\right)$ increases substantially after the shift, in agreement with the observed chlorophyll changes described by Venrick et al. (1987). ecosystem model with multiple nutrients and phytoplankton groups (Chai et al. 2002a) into an ocean general circulation model (OGCM) of the Pacific Ocean. In general, the phytoplankton spring blooms in the northwest Pacific are stronger after 1975-76

(Fig. SBI), which is consistent with changes in the modeled nutrient conditions in the upper $100 \mathrm{~m}$ of the ocean. The strongest change occurs between 1964-75 and 1978-92. Haigh et al. (200I), in a model of the North Pacific, found phytoplankton and zooplankton biomass generally increased post-1976 over the subarctic gyre due to a deepened mixed layer that entrained more nutrients. Similar observed changes of phytoplankton biomass in the North Pacific have been documented by many researchers, for example, a twofold increase in integrated chlorophyll-a observed during summer (Venrick et al. (987). 
at the surface has changed over the last few decades (McPhaden and Zhang 2002). Ocean hindcasts (Nonaka et al. 2002) show that these wind-driven changes explain part of the interdecadal anomalies of tropical SST.

Some researchers suggest that a significant fraction of the dominant pattern of interdecadal SST variability in the North Pacific is driven by tropical forcing via atmospheric teleconnections, the so-called atmospheric bridge (Lau and Nath 1996; Alexander et al. 2002). Recent fully coupled modeling studies suggest that the tropical Pacific alone can also support interdecadal climate variability (Liu et al. 2002). Jin (2001) found that interdecadal equatorial thermocline oscillations are possible in a linear shallow-water ocean on an equatorial $\beta$ plane when adjustments in higher latitudes are included.

Alternatively, nonlinearities can lead to variance at interdecadal timescales without a classic memory timescale (such as mean advection or Rossby wave traveling times). Interactions between ENSO and the annual cycle lead to ENSO irregularity and temperature variance on interdecadal timescales through the quasiperiodicity route to chaos (Jin et al. 1994; Tziperman et al. 1994; Chang et al. 1996). Decadal variability in the Tropics also emerges as a natural consequence of nonlinear temperature advection (Timmermann 2003; Timmermann and Jin 2002). A linearly unstable ENSO mode grows until the zonal temperature advection from the warm pool to the eastern equatorial Pacific becomes so small that the warm pool thermocline depth is readjusted to its radiative-convective equilibrium state. This resets the growing ENSO mode. The typical period between warm pool resettings-may be several decadeswould explain the emergence of interdecadal ENSO amplitude modulations, ENSO irregularity, as well as interdecadal tropical variability.

Biological influences on climate physics. The atmospheric climate is modified and, in some instances, controlled by oceanic biological processes. Oceanic ecosystems may modify the flow of radiant energy in at least two ways. The first is through the effect of phytoplankton on upper-ocean absorption of solar radiation. The second is through the flux of dimethylsulfide (DMS) to the atmosphere, which affects cloud formation.

Phytoplankton efFects on upper-ocean radiation ABSORPTION. Varying phytoplankton biomass in the upper ocean changes the in-water solar transmission. In the upper ocean, solar energy decays exponentially with depth following the Beer-Lambert relation. This $e$-folding, or attenuation, scale is a function of wavelength and can be quantified with the diffuse attenuation coefficient spectrum. Both pure seawater and its constituents contribute to solar attenuation. The diffuse attenuation coefficient for optically pure water is considered constant. Changes in chlorophyll biomass, present in phytoplankton, and its covarying materials (hereafter termed "chlorophyll") are primarily responsible for variations in solar attenuation, or transmission, in open ocean waters. The associated modification of the vertical divergence of the solar energy leads to variations in the vertical distribution of heating. This affects the upper-ocean stratification, influences vertical mixing, and can lead to changes in SST, longwave, latent and sensible heat exchange with the atmosphere, and oceanic and atmospheric circulation patterns.

There are only a few studies that address the sensitivity of OGCM results to variations in solar transmission due to biology. Schneider and Zhu (1998) investigated the effects of solar transmission beyond $30 \mathrm{~m}$. Inclusion of solar penetration causes an increase in mixed layer depth by up to $30 \mathrm{~m}$. The storage of heat in a deeper layer decreases both the annual cycle and annual mean SST by as much as $1^{\circ} \mathrm{C}$. Solar penetration increased the annual zonally averaged temperature near $50 \mathrm{~m}$ by as much as $5^{\circ} \mathrm{C}$. A deeper mixed layer in the western equatorial Pacific causes a decrease in the sensitivity of SST to upwelling. Reduced amplitude in the annual SST cycle off the equator leads to weaker easterly wind stress (up to $0.2 \mathrm{dyn}^{-2}$ ) in the equatorial region, ultimately reducing zonal currents (by more than $4 \mathrm{~cm} \mathrm{~s}^{-1}$ ), and eastern Pacific upwelling. The mean and annual cycle of SST are more realistic when solar penetration is considered.

Nakamoto et al. (2001a) use an OGCM to study effects of a space-time-varying chlorophyll distribution [see also Nakamoto et al. (2001b) for effects of living versus dead phytoplankton]. A chlorophylldependent simulation yielded shallower mixed layer depths throughout most of the equatorial region (more solar energy trapped near the surface) than a simulation fixed at clear-water conditions. A shallower mixed layer with decreased penetration of solar radiation is consistent with previous results (Schneider et al. 1996; Schneider and Zhu 1998; Nakamoto et al. 2000). The simulation with seasonaland space-dependent chlorophyll produced SST values that are up to $2^{\circ} \mathrm{C}$ lower in the eastern equatorial Pacific when compared with the results with chlorophyll fixed at "clear water" levels. This cooling is due to $3 \mathrm{D}$ dynamical effects where mixed layer shoaling along the equator results in anomalous westward currents. The consequent increased westward surface 
flow indirectly increases upwelling and horizontal temperature advection that cools SST. This mechanism suggests that anomalous upwelling in the eastern equatorial Pacific is associated with the horizontal thermal gradient induced by chlorophyll pigments. The Nakamoto et al. (2001a) modeling work shows that the circulation of the equatorial Pacific is quite sensitive to light penetration and to processes that maintain the thermocline.

A colder than observed equatorial cold tongue plagues many state-of-the-art coupled ocean-atmosphere models and forced OGCMs. Murtugudde et al. (2002) argue that using an appropriate attenuation depth can remedy the problem. Heat trapping by phytoplankton destabilizes the upper ocean and leads to deeper mixed layers, weaker surface currents, reduced divergence, and hence warmer cold tongue SST.

The ocean's feedbacks to the atmosphere following chlorophyll-induced SST changes have only recently been investigated. Absorption of solar radiation by phytoplankton can amplify the positive feedback between boundary layer stratiform cloudiness and SST (see, e.g., Norris and Leovy 1994). Increased SST due to phytoplankton absorption would act to decrease cloud amount, increase transmitted radiation, and thus produce an additional SST increase (Sathyendranath et al. 1991). The phytoplankton SST anomaly patterns found by Nakamoto et al. (2001a) correspond to regions where cloud-SST anomaly correlations are greatest and likely most sensitive to changes in SST. Shell et al. (2003, manuscript submitted to J. Geophys. Res., hereafter SFNS) use the SST (Fig. 2) from the Nakamoto et al. (2001a) study to force an atmospheric GCM [version 3 of the Community Climate Model (CCM3)]. The primary influence of decreased solar penetration and elevated SST on the atmosphere is a $\approx 0.3^{\circ} \mathrm{C}$ amplification of the seasonal cycle in the lowest atmospheric layer (Fig. 3). Additionally, the annual mean atmospheric temperature is slightly warmer $\left(\approx 0.05^{\circ} \mathrm{C}\right)$ when chlorophyll concentration is considered in determining SST. Atmospheric temperatures over land can change by $1^{\circ} \mathrm{C}$. Additional studies of the atmospheric sensitivity to SST anomalies induced by ocean biology are clearly of interest.

PhytoplankTon EFFeCTS On DMS FLUXEs. Dimethylsulfide is the most abundant form of volatile sulfur $(S)$ in the ocean and is the main source of biogenic-reduced $S$ to the global atmosphere (Andreae and Crutzen 1997). The sea-air flux of $S$ due to DMS is estimated to be 15-33 teragram $S y^{-1}$, which constitutes about $40 \%$ of the total atmospheric sulfate burden (Erickson et al. 1990; Chin and Jacob 1996). In the atmosphere,
DMS is rapidly oxidized to form non-sea-salt sulfate (nss- $\mathrm{SO}_{4}^{2-}$ ) and methanesulfonate (MSA) aerosols. A significant fraction of these aerosols may act as cloud condensation nuclei (CCN), thus influencing the radiation budget of the atmosphere and possibly affecting climate variability on many timescales.

Various species of phytoplankton produce differing amounts of dimethylsulfoniopropionate (DMSP), the precursor to DMS. In general, coccolithophorids and small flagellates have higher intracellular concen-

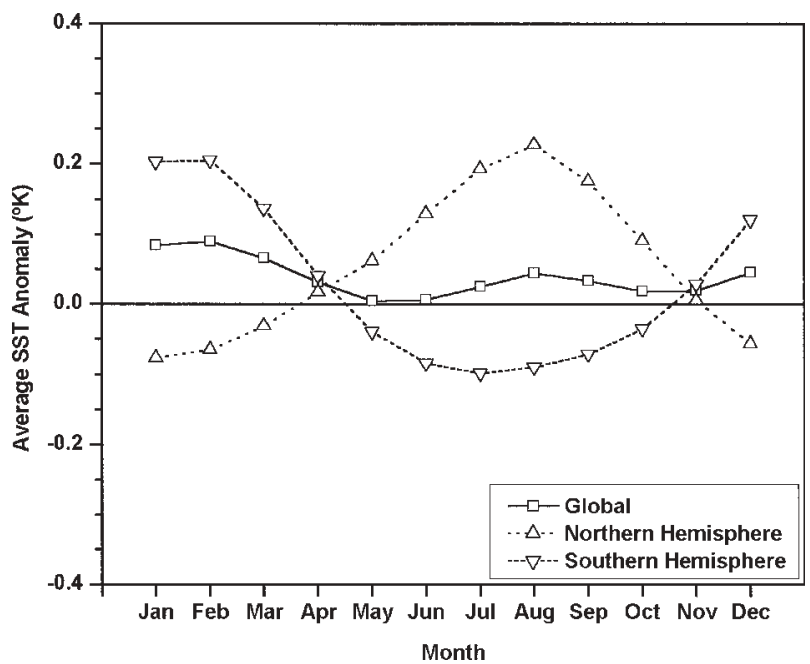

FIG. 2. SST anomaly, averaged over the Northern Hemisphere (triangle), Southern Hemisphere (inverted triangle), and globe (square), induced by including the annual cycle spatial distribution of observed chlorophyll from coastal zone color scanner (CZCS) in a full-physics ocean model of Nakamoto et al. (200 la). From SFNS.

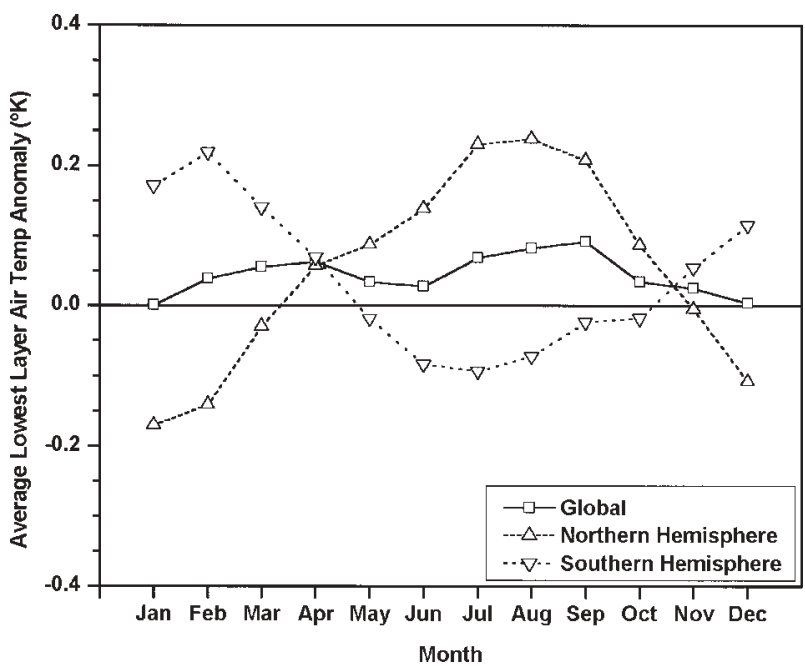

FIG. 3. Atmospheric model response, expressed as surface air temperature averaged over the Northern Hemisphere (triangle), Southern Hemisphere (inverted triangle), and globe (square), to the SST anomaly pattern of Fig. 3. From SFNS. 
trations of DMSP, which is thought to act as an osmolyte in the algal cell. Shaw (1983) and then Charlson et al. (1987) postulated links between DMS, atmospheric sulfate aerosols, and the global climate. It was hypothesized that an increase in biogenicly produced sulfate aerosols would lead to formation of more CCN, and brighter clouds. This change in cloud microphysics could cool the earth's surface and thus stabilize climate to perturbations due to greenhouse warming. While phytoplankton are protagonists in this feedback loop, recent results suggest that the entire food web determines net DMS production and not just algal taxonomy (Simo 2001).

The proposed DMS-climate link, later called the CLAW hypothesis after the authors of the Charlson et al. (1987) paper, stimulated a flurry of research in the 1990s and several hundred scientific publications, but is still to be verified. Attempts to assess the direction and magnitude of the DMS-climate feedback (Foley et al. 1991; Lawrence 1993; Gabric et al. 1998) in the context of global warming due to increased greenhouse gases suggest the likelihood of a small, negative feedback (stabilizing), with magnitude of the order of $10 \%$, and considerable uncertainty. These studies have all concluded that a feedback would occur over multidecadal timescales. They did not, however, attempt to link the spatial structures of interdecadal climate variations to regional alterations of DMS production by the ecosystem and hence to possible feedback loops. Moreover, there are no seawater DMS time series long enough for evaluating the CLAW hypothesis on interdecadal timescales.

Bates and Quinn (1997) collated data from 11 cruises from 1982 to 1996 in the equatorial Pacific and reported that mean DMS levels during El Niño periods were not significantly different from those in normal years. Despite the major physical changes during the 1992 El Niño, the chemical and biological variability was small (Murray et al. 1994). Primary production did decrease, but apparently due to reduced numbers of larger diatoms, which are not major DMS producers. In contrast to the Bates and Quinn (1997) study, Legrand and Feniet-Saigne (1991) found good correlation between El Niño events and high MSA concentrations in south polar snow layers deposited from 1922 to 1984 presumably due to enhanced DMS concentrations at high southern latitudes during El Niño years. Legrand and Feniet-Saigne (1991) suggest this could have been due to higher sea surface wind speed (implying increased sea-air exchange), or variations in sea ice cover, which can affect ocean salinity and hence the osmotic balance in the algal cell for which DMSP is thought to have a regulating role. Atmospheric measurements at Cape Grim, Tasmania $\left(41^{\circ} \mathrm{S}, 145^{\circ} \mathrm{E}\right)$, illustrate the strong seasonality in DMS (Ayers et al. 1991; Boers et al. 1994). A multidecadal time series of observations there (Fig. 4) shows considerable interannual variability in the magnitude of the MSA peak, while the strong seasonality and early January timing of the MSA maximum remain remarkably consistent.

In the absence of long-term oceanic time series, modeling can provide some insight into the potential for an interdecadal feedback. A regional DMS production model in the subantarctic Southern Ocean showed considerable interdecadal variability in the annual integrated DMS flux (Fig. 5), suggesting the potential for a significant DMS response to changes in physical forcings (Gabric et al. 2001).

The species assemblage shift accompanying the 1976 climate shift may have changed the distribution of DMS-producing species. This may have resulted in a different distribution of DMS-related atmosphere

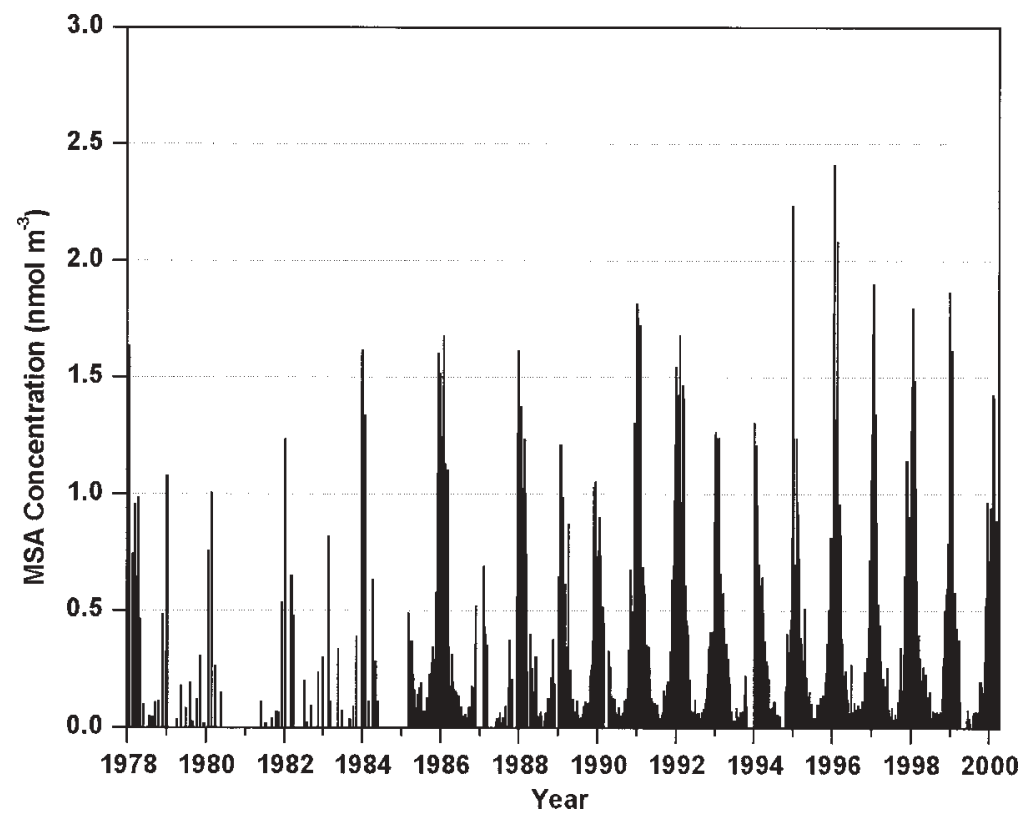

FIG. 4. Methanesulfonate aerosols (oxidized DMS) measured at Cape Grim (Tasmania) 1978-2000 showing interdecadal variations in one of the few interdecadal-scale time series available. Ticks on abscissa indicate I Jan for a given year. 


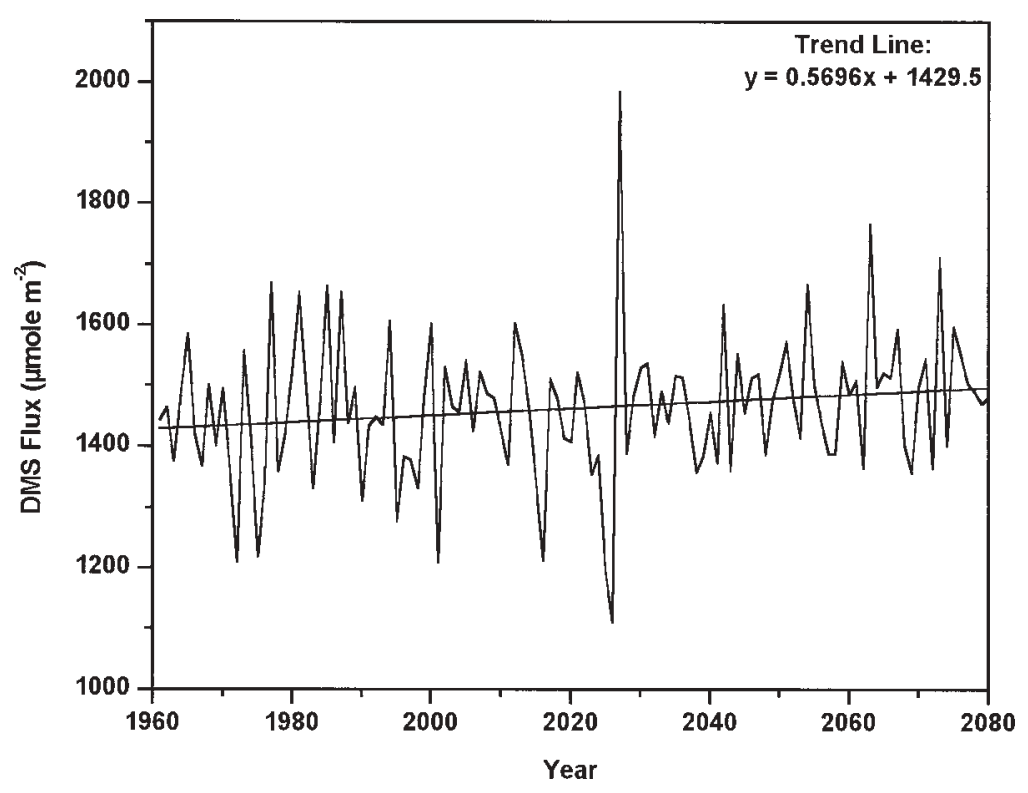

FIG. 5. Modeled annual DMS flux in the subantarctic Southern Ocean. The regional DMS production model, forced with temperature, cloud, wind speed, and mixed layer depth data yields variations with interdecadal timescales. From Gabric et al. (200I).

particles interacting with atmospheric radiation, an example of unexplored physical consequences of interdecadal biological changes.

Note that another sulfur-containing biogenic gas, carbonyl sulfide (OCS), is produced in the ocean from dissolved organic sulfur compounds. It is the most abundant sulfur gas in the background atmosphere. Ocean emission contributes to about $20 \%$ of the OCS sources (Andreae and Crutzen 1997). Like DMS, OCS can be oxidized to sulfur oxide gas and then to sulfate aerosols, but only in the mid- to lower stratosphere where wavelengths are sufficiently energetic to break the C-S bond (e.g., Chin and Davis 1995). This process has produced a veil of aerosols that reflects incoming solar radiation and helps to cool the planet, the so-called Junge layer. Since OCS is obtained from biological reactions at the surface and is not reactive in the troposphere, it may reside in the atmosphere for a long time. Its overall chemical lifetime is $29 \mathrm{yr}$. On a decadal timescale, changes in OCS emissions to the atmosphere due to changes in phytoplankton biomass can affect the sulfate burden of the stratosphere, the reflection of solar radiation back to space, and therefore climate.

AdDITIONAL CONSIDERATIONs. Nutrient cycling changes may modulate the above two mechanisms because nutrients limit the growth of phytoplankton. The limiting nutrients include nitrate, phosphate, silicate, and iron. Ocean physics can control the flux of these nutrients to the regions where radiation effects and DMS fluxes influence climate variability and must therefore be accounted for on interdecadal timescales. The frequency and intensity of Asian dust storms (which carry iron to the open ocean) may also have some interdecadal signals that could alter ocean productivity on this scale.

Other, more subtle, effects may also come into play. The transfer velocity of gases at the air-sea interface is a function of sea surface turbulence (Wanninkhoff 1992), which suggest significant feedbacks with climate. For example, for a fixed surface ocean concentration of DMS, an increase in the wind speed would increase the flux of DMS from the ocean to the atmosphere. Also, a change in chlorophyll concentration from 0.03 to $30 \mathrm{mg} \mathrm{m}^{-3}$ decreases sea surface albedo by about 0.005 . The resulting change in reflected solar flux is about $1 \mathrm{~W} \mathrm{~m}^{-2}$ at the top of the atmosphere (Frouin and Iacobellis 2002). This value is not negligible compared with the radiative forcing since preindustrial times due to greenhouse gases, which over the ocean ranges from 1 to $3 \mathrm{~W} \mathrm{~m}^{-2}$ (e.g., Kiehl and Briegleb 1993). If the phytoplankton abundance of the oceans should increase due to global warming, it would contribute to a warmer climate, not only by trapping more heat near the surface, but also by decreasing surface albedo. However, the relationship between phytoplankton abundance and surface albedo is nonlinear, and a large increase in abundance from current levels would be required for the negative climate feedback to be effective (Frouin and Iacobellis 2002).

The possible drawdown of nutrients [nitrate $(\mathrm{N})$ and phosphate $(\mathrm{P})]$ in high-nutrient, low-chlorophyll (HNLC) regions, particularly in the Southern Ocean, and changes in the production of calcium carbonate are potentially major negative feedbacks on the accumulation of atmospheric $\mathrm{CO}_{2}$. Stratification of the Southern Ocean, whether due to temperature or salinity effects (e.g., partial melting of the Antarctic ice cap), would reduce the input of macronutrients to surface waters and give Aeolian iron inputs a chance to catch up with the input of $\mathrm{N}$ and $\mathrm{P}$ from upwelling. A complete drawdown via photosynthesis of excess $\mathrm{N}$ and $\mathrm{P}$ in the ocean could reduce atmospheric $\mathrm{CO}_{2}$ concentrations to 100-140 ppm (Sarmiento and Wofsy 1990). Since atmospheric $\mathrm{CO}_{2}$ concentrations are cur- 
rently increasing at a rate of $3.3 \mathrm{ppm} \mathrm{yr}^{-1}$, such a drawdown of excess $\mathrm{N}$ and $\mathrm{P}$ would offset the current rate of accumulation of $\mathrm{CO}_{2}$ in the atmosphere for $70-80 \mathrm{yr}$.

Studies with both coral reef communities and coccolithophorids have shown that a reduction in the saturation state of calcium carbonate due to the accumulation of $\mathrm{CO}_{2}$ in the surface water of the ocean will very likely decrease the rate of calcium carbonate production (Gattuso et al. 1998; Kleypas et al. 1999; Leclercq et al. 2000). Riebesell et al. (2000), for example, have shown that increasing the atmospheric $\mathrm{CO}_{2}$ concentration from 280 to $750 \mathrm{ppm}$ reduces the calcification rates of the coccolithophorids Emiliania huxleyi and Gephyrocapsa oceanica by $16 \%-83 \%$. However, the increase in seawater $\mathrm{CO}_{2}$ concentrations will also reduce the buffer capacity of seawater, causing more $\mathrm{CO}_{2}$ to be released per $\mathrm{CaCO}_{3}$ precipitated. Furthermore, reduction in pelagic $\mathrm{CaCO}_{3}$ production may lead to less efficient ballasting and ultimately the burial of exported organic carbon. While a reduction in $\mathrm{CaCO}_{3}$ production will exert a negative feedback on the accumulation of $\mathrm{CO}_{2}$ in the atmosphere, the concomitant reduction in buffer capacity of surface seawater and ballasting of exported organics will reduce the impact of this feedback to an extent that is unclear at this time.

A major uncertainty in quantifying the feedback between biological systems and their environment is the resiliency and adaptability of biological communities due to their genetic diversity, phenotypic plasticity, and evolutionary potential. Efforts to develop a theoretical understanding of the manner in which ecosystems adapt to environmental change date from the work of Lotka (1922), who postulated that natural selection tends to maximize the energy flux through a system, at least within the constraints to which the system is subject. Odum (1983) expanded on Lotka's theory. He argued that natural systems tend to maximize power, and that theories and corollaries derived from the maximum power principle could explain much about the structure and processes of these systems. In rationalizing the application of the maximum power principle to ecosystems, Odum drew analogies between ecosystem behavior and the laws of thermodynamics. A number of authors have explored the application of analogs of thermodynamic principles to the behavior of natural systems (Jorgensen 2000; Jorgensen and Straskraba 2000), and these thermodynamic approaches have met with considerable success in estimating parameters to describe real ecosystems.

In a recent paper Cropp and Gabric (2002) employed a genetic algorithm to simulate the evolution- ary response of the biota of a model ecosystem. The simulation was that the optimal parameter values proved to be very insensitive to the choice of selection pressure. In particular, the simulations suggested the hypothesis that within the constraints of the external environment and the genetic potential of their constituent biota, ecosystems evolve to the state most resilient to perturbation.

Laws et al. (2000) have applied the hypothesis of maximum resilience to a more complex food web model of an open ocean pelagic ecosystem, similar to that of Cropp and Grabric (2001). Two parameters were allowed to adapt so as to maximize the resiliency of the steady-state solution: the relative growth rate (Goldman 1980) of the large phytoplankton and the biomass of the filter feeders. Comparisons between the model predictions and field observations of the Joint Global Ocean Flux Study and related work (Fig. 6) clearly support the assumption that pelagic marine ecosystems tend to evolve toward a condition of maximum resiliency. The model results suggest that an increase in the SST due to global warming would lead to less efficient export of organic matter to the interior of the ocean. More of the organic matter that was exported would probably take the form of dissolved organic carbon, and the efficiency of the biological pump would be reduced. This would amount to a positive feedback to global warming.

The drawdown of macronutrients ( $\mathrm{N}$ and $\mathrm{P}$ ) in HNLC regions, particularly the Southern Ocean, and changes in ballasting of exported organics (calcium carbonate versus silica) are possibly major feedbacks. The most likely mechanism leading to a switch from calcium carbonate to silica would be a reduction in $\mathrm{pH}$. However, diatoms cannot make silica without silicate, so there is a limit on how far that transition can go.

\section{COUPLED PHYSICAL-BIOLOGICAL EF- FECTS IN PACIFIC INTERDECADAL VARIABILITY. Stochastic excitation. Even in the con-} text of stochastic excitation of oceanic interdecadal variability, biological feedbacks may be important. For example, thermal forcing of SST anomalies (e.g., Hasselmann 1976; Barsugli and Battisti 1998), may be modulated by the ecosystem feedback. In an SST field cooled by upwelling of nutrient-rich waters, an increased concentration of phytoplankton driven by the nutrient injection would warm SST through increased surface layer absorption, producing a negative feedback. In an SST field driven by surface heat fluxes, warmer SST could increase the phytoplankton growth rates, producing increased surface layer absorption and a positive feedback. 

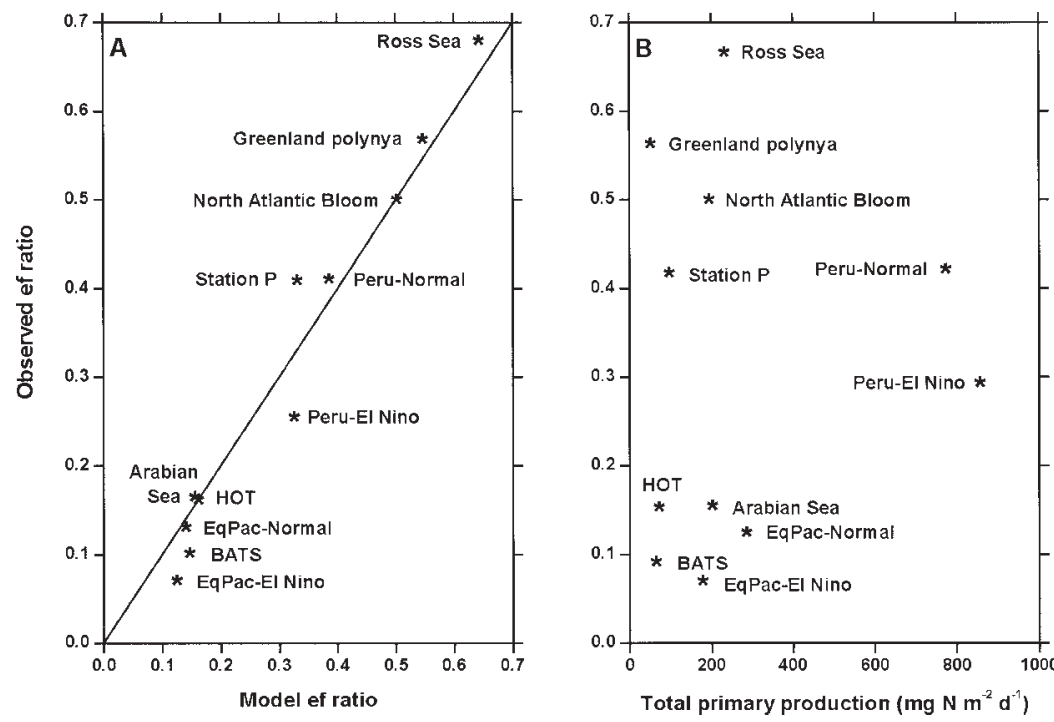

the ability of the biology to significantly affect the climate system either directly, for example, by changing the profile of heating in the upper ocean, or indirectly, for example, by affecting the flux of radiation via changes of clouds. Additionally, properties of subducted waters are believed to be set during times of deepest mixed layer formation during strong storms (Stommel daemon). It remains to be seen if variations of the nutrients at these source regions or changes in buildup of nutrients in the thermocline during the equatorward transit control the concentrations of waters upwelled at the equator.

The ecosystem likely has a negaFig. 6. (a) Model ef ratios versus observed ef ratios. The model is a complex food web for an open-ocean pelagic ecosystem and the observations are from field studies carried out as a part of the Joint Global Ocean Flux Study and related work. Because the system was assumed to be in steady state, the export ratio $\mathrm{e}=$ export production/total production equals the $f$ ratio $=$ new production/total production (Eppley and Peterson 1979) and was designated the ef ratio. The straight line is the I: I line. (b) Total primary production ( $\mathrm{mg}$ nitrogen $\mathrm{m}^{-2}$ day $^{-1}$ ) vs observed $f$ ratios at the same locations. From Laws et al. (2000).

The subduction mode. The subduction mode can apparently be influenced by biological processes in several ways (Fig. 7). The effect of upwelling on tropical Pacific SST includes a response to the changing ecosystem so that the amplitude of tropical SST anomalies is changed in the presense of biology (cf. Murtugudde et al. 2002; Nakamoto et al. 2001a). This, in turn, affects the strength of the atmospheric teleconnections to the midlatitudes via the Hadley cell as well as to other tropical oceans via the Walker cell (Murtugudde et al. 2001). But these atmospheric teleconnections could also be influenced by the DMS influence on CCN. The midlatitude SST anomalies could also be altered by biological feedbacks including phytoplankton radiation absorption and local DMS effects on cloud formation and atmospheric response. If water masses that are subducted from the midlatitudes or subtropics into the tropical upwelling zones contain nutrients that limit the growth of tropical ecosystems, then the strength of tropical biological response can be modulated as well. Recent studies suggest that the subduction effect is particularly significant at multidecadal timescales (e.g., $50 \mathrm{yr}$ or longer; Shin and Liu 2000). Therefore, it is possible that the coupled biological effect for this mechanism would also play a more important role at multidecadal timescales. These possibilities depend, however, on weaken, reduced upwelling, a relaxed thermocline and nitracline, and reduced entrainment can lead to enhanced subsurface warming by weakening the stratification, deepening the mixed layer, reducing the divergence and upwelling further. Since the zonal winds along the equator have strong correlations to off-equatorial SST (Schneider and Zhu 1998), the equatorial ecosystem effects on circulation may affect subtropical subduction zones.

The midlatitude gyre mode. The midlatitude gyre mode may be influenced by biological processes as well (Fig. 7). The Kuroshio-Oyashio Extension (KOE) region is where the midlatitude North Pacific atmosphere is most sensitive to SST anomalies in uncoupled atmospheric models (Peng et al. 1997) and in full-physics coupled models (Schneider et al. 2002). Since ocean dynamics control the SST in the KOE on interdecadal timescales (e.g., Schneider and Miller 2001), changes in the ecosystem in that region could influence a coupled feedback loop in two ways. First, the amplitude of the SST anomaly may be altered by the phytoplankton radiation absorption effect. This may be a negative feedback if upwelling (which drives the cold phase of SST) increases phytoplankton absorption effects. Second, the atmospheric response which completes the gyre mode feedback loop could 
potentially be affected by the flux of DMS into the atmosphere, its effect on clouds, and the flow of energy. Such a feedback is rather hypothetical at this point but potential effects are unknown and need to be explored in this context. The seasonality of the physical and biological processes is particularly important. The physical processes associated with the gyre mode are dominated by winter conditions, while biological activity and its effect on solar radiation peaks during the spring.

The reemergence mechanism. There are various ways in which biological processes could interact with the reemergence mechanism and the atmospheric bridge. Both physical processes influence SST and mixed layer depth, which affect primary productivity and thus the amount of light absorbed in the water column. The biology can, in turn, feed back upon the temperature profile of the upper ocean. During years with low productivity and deep solar absorption, this can alter the temperature anomalies sequestered below the seasonal thermocline by enhanced vertical mixing. In contrast, high solar absorption near the surface during productive years can insulate the deeper layers and should increase the year-to-year persistence of winter temperature anomalies. In addition to its influence on temperature, the reemergence process may alter the seasonal evolution of other quantities such as nutrients or plankton. For example, nutrient-rich (or poor) water sequestered below the mixed layer at the end of one winter may return in the subsequent fall/winter. Biological processes could also affect the atmospheric bridge (a remote forcing in this context) indirectly by changing the amplitude and/or frequency of SST anomalies in the equatorial Pacific by altering the oceanic absorption or directly by changing the fluxes of DMS into the tropical atmosphere. While it is likely that feedbacks between ocean biology and the reemergenceatmospheric bridge process influence climate variability, the strength and importance of the effect is unclear. There is no reason to expect the process to instigate oscillations with a preferred interdecadal period.

Indirect biology-physical feedback mechanisms. Biology may redistribe heat by affecting absorption in the ocean column, for instance, or by altering another component of the system (e.g., as in the proposed DMS/cloud effect). Other indirect feedback effects may also occur; for instance, changes in temperature might affect biological processes that in turn affect the ice albedo and/or the albedo of the ocean at the ice margin. The albedo effect of the biology would be magnified by the strong physical ice-albedo feedback itself. Biological modification/enhancement of strong physical feedback mechanisms may well provide the most likely route for important biological-physical coupling.

Nonlinear tropical modes. If tropical interdecadal variability results from the nonlinear interaction of the seasonal cycle and ENSO (Jin et al. 1994; Tziperman et al. 1994), the documented sensitivity of the former to changes of absorption (Schneider and Zhu 1998; Murtugudde et al. 2002) might affect the interdecadal timescales. Assuming that without biology, ENSO and the annual cycle operate in a frequency-locked regime, a modification of the amplitude of the annual cycle by about $0.3^{\circ} \mathrm{C}$ might lead to chaotic ENSO oscillations. The existence of chaotic ENSO variability implies that interdecadal timescale variability is ex-

\section{Subduction Mode with Biology}

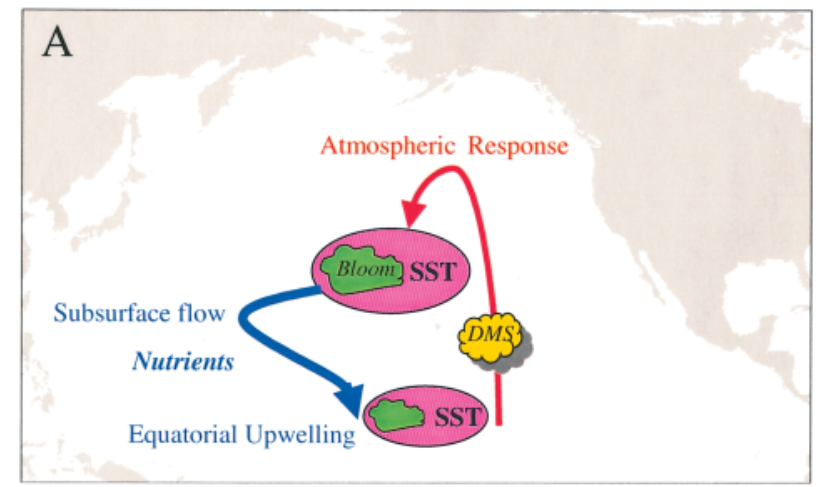

\section{Midlatitude Gyre Mode with Biology}

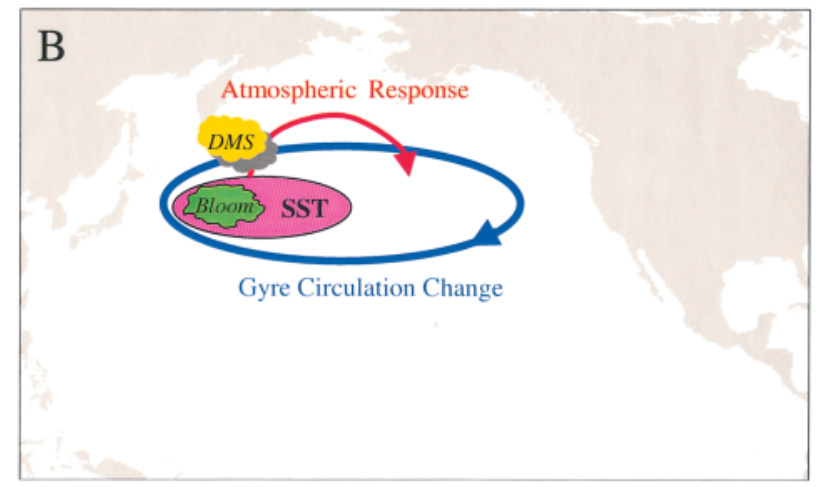

Fig. 7. Sketch of the possible effects of ocean biology on the subduction mode and midlatitude gyre mode described in Fig. I. Changes in upper-ocean heating due to phytoplankton modify SST anomalies, while changes in DMS fluxes to the atmosphere modify atmospheric clouds and dynamics. Ascertaining the strength and importance of these effects requires further study. 
cited. Hence, the modification of the annual cycle due to biology might generate changes in the amplitude of interdecadal variability. How such changes feed back onto the biology, to form a coupled physicalbiological feedback loop, is unclear.

Synopsis. Oceanic ecosystems may influence hypothetical interdecadal climate variability mechanisms in the Pacific. Biological processes do not, however, appear to be able to establish a timescale via delayed feedback in these modes. Instead, biology is likely to sensitize or desensitize the physical ocean-atmosphere interactions, mainly through altered SST through phytoplankton-radiation effects and altered atmospheric dynamics through DMS fluxes. The strength and importance of these feedbacks is unknown and requires further study.

The equatorial region is a key area requiring attention. The large incident solar radiation and the importance of solar absorption offers the possibility that biological mechanisms affect the physical environment directly. In turn, the strong atmospheric response to SST anomalies in the tropical region (and its role in the subduction mode) provides the possibility of closing a feedback loop. The KuroshioOyashio Extension region (the heart of the midlatitude gyre mode) is another "hot spot" where midlatitude ocean-atmosphere feedbacks are possible. In both regions, the effects of phytoplankton on upper-ocean absorption and changes in the atmospheric response due to DMS effects on cloudiness are the postulated mechanisms, although their strengths and effectiveness are currently unknown.

The possible amplification of small biological perturbations by powerful physical feedback mechanisms, such as the ice-snow albedo feedback, give the possibility also of high-latitude effects, although no obvious mechanisms have been proposed.

RESEARCH CHALLENGES. Given the complexity of the physical-biological feedback problem, we now discuss what lines of research might be best followed to better understand these effects in interdecadal Pacific climate variations.

Modeling strategies. The identification of important biological mechanisms using local or column atmosphere, ocean, and ecosystem models of varying complexity (both coupled and uncoupled) is clearly the first step in the process. Biologically mediated perturbations to the radiative balance, can best be tested with such local models. Since, undoubtedly, a range of climate-related biological-physical interactions re- mains unrecognized, it is particularly important to be sensitive to the possibility of such interactions and to test them in such models.

Oceanic biological models now range from the simple single currency nitrate-phytoplanktonzooplankton model to multiple currency models that have scores of degrees of freedom. It is difficult to validate the more complicated models due to a lack of observations. But it would be ideal to intercompare these models both in the uncoupled mode and in the coupled column model to assess the necessity of including a large number of dependent variables insofar that they affect the structure of radiative and DMS response for instance.

Variations in upper-ocean phytoplankton biomass can promote changes in solar transmission within the water column, which can subsequently impact climate. Climate models must adequately represent inwater solar flux divergences for accurate simulations. While a sophisticated representation is computationally impracticable, a simple single exponential solar transmission parameterization based on chlorophyll concentration is a necessary component of climate models hoping to produce accurate results. Such a parameterization should give transmission values with less than $10 \%$ error for depths beyond $10 \mathrm{~m}$ (Ohlmann et al. 1998). The description of solar transmission in modeling studies is often limited to a statement of solar transmission parameter values with little regard for what the values actually mean in terms of upper-ocean chlorophyll concentration. For investigating biological feedbacks with interdecadal climate variations, it is necessary to think first of changes in phytoplankton biomass, followed by changes in the corresponding solar transmission parameters rather than bypassing any thought or mention of chlorophyll concentration.

Local models necessarily lack the dynamical aspect that redistributes local perturbations throughout the system and allows new modes of variation and new feedback mechanisms to exist. The cost and complexity of integrating dynamical models of the atmosphere and ocean for the hundreds of years needed to investigate interdecadal climate variations means that models must be operated at comparatively coarse resolution with grid sizes ranging from several hundreds of kilometers for global models to tens of kilometers for regional models. Thus, the second step, subgrid-scale physical and biological processes, must be parameterized for global and regional coupled models.

Uncoupled global and regional models are used to determine the sensitivity of the individual components in the subsequent step. For instance, the sensitivity of the atmosphere to changes in the DMS fluxes 
may be investigated with an uncoupled atmospheric model. The DMS flux can be compared against a simulation made without DMS fluxes. In a similar vein, an ocean-ecosystem model could be forced with observed atmospheric forcing over decades and the results verified against observations with special attention to the tropical Pacific and the KOE region.

The fourth and final step is multicentury simulation with fully coupled atmosphere-ocean-ecosystem models. It may not be suitable to isolate parts of the Pacific using regional models, although this depends on the investigation. Clearly the signal-to-noise ratio of the biological effects must be assessed by simulations with and without ocean biology. Follow-up runs should include successively more sophisticated biology to determine the importance of refinements and the conditions for importance. An important goal of the coupled biological-physical models will be to assess the potential of HNLC regions to draw down excess $\mathrm{N}$ and $\mathrm{P}$ in response to changes in physical circulation. Another goal will be to quantify the combined impact on the biological and solubility pumps of reduced calcification, reduced buffer capacity, and reduced ballasting of exported organics caused by increases in upper-ocean $\mathrm{CO}_{2}$ concentrations. Biological models targeting interdecadal changes must allow for the evolutionary potential of biological communities, and particularly of organisms such as plankton with short generation times. As noted by Hutchinson (1967, p. 376), "The annual cycle [of a plankton community] is thus, in terms of generation time, the equivalent of perhaps up to ten thousand years in the successional history of . . . some forest trees." Resilience of biological communities appears to be a common consequence of evolutionary pressures.

It is quite possible that in a decade or so, computational power will allow integration of fully coupled ocean-atmosphere-biogeochemical models for routine climate forecasts. The models and the technology exists currently to quantify the potential feedback of the ecosystem to the coupled climate variability on ENSO timescales. How does the ecosystem affect the amplitude, frequency, or phase of ENSO and the feedbacks between tropical ecosystems and extratropical climate? Observational strategies. Sustained long-term observations of biological and physical variables in key regions of the Pacific Ocean will be necessary to determine the importance of biological feedbacks on interdecadal climate variations. These will also help clarify whether there are truly preferred timescales of climate variability in the Pacific. This effort will require commitments by the international community. For example, the California Cooperative Oceanic
Fisheries Investigations has been observing biology and physics for 50 years off the coast of southern California, which has resulted in a very important physical-biological dataset. But it turns out that this is not a key region of ocean-atmosphere interaction. Our knowledge now is advanced to the point that we can make a good guess where the hot spots are (while still allowing for as yet unrecognized possibilities).

At least two potential hot spots of biological response and physical sensitivity have been identified. The primary region is the tropical Pacific, because of the large flow of energy. The second region is the Kuroshio-Oyashio Extension, because of its central importance in midlatitude ocean-atmosphere feedbacks. Long-term measurements there of chlorophyll and DMS fluxes, physical oceanographic variables (temperature, salinity, and currents) and atmospheric variables (pressure, winds, clouds, and surface heat fluxes) are needed. Also useful would be measurements of biological variables such as nutrient concentrations $\left(\mathrm{NO}_{3}, \mathrm{Fe}, \mathrm{SiO}_{4}\right)$, biomass, productivity, vertical distributions, zooplankton, sedimentation, and $\mathrm{CO}_{2}$.

Existing remote sensing of ocean color, SST, winds, humidity, sea level, etc., from satellites and subsurface temperature, salinity, and velocity from profiling floats will prove invaluable to the long-term study of these coupled biological-physical climate processes. New satellite strategies also need to be devised to measure large-scale phytoplankton species distributions and aerosol characteristics, including their relation to cloud microphysical properties and other atmospheric sensitivities.

Oceanic biology is rich in fascinating detail, and marine ecosystems can exhibit extremely complex dynamical behavior. Naturally, there is no end to the list of observations that biologists would consider essential to document biotic responses and feedbacks to the climate system. Thus a key element in strategies for the future must be the use of the coupled models in identifying gaps in our knowledge of how the coupled biological-physical systems function and in identifying the variables and parameters to which the models are most sensitive. Only in this way can we hope to optimize our observing strategy in what will still be an undersampled system.

CONCLUSIONS. The representation of basic biological processes on land and in the oceans will be part of future climate variability and change investigations. Here we have attempted to assess the potential role of marine ecosystems in interdecadal climate variations. In particular, we summarized the processes and uncertainties (see Fig. 8) and have asked if biological 


\section{Local Forcings}

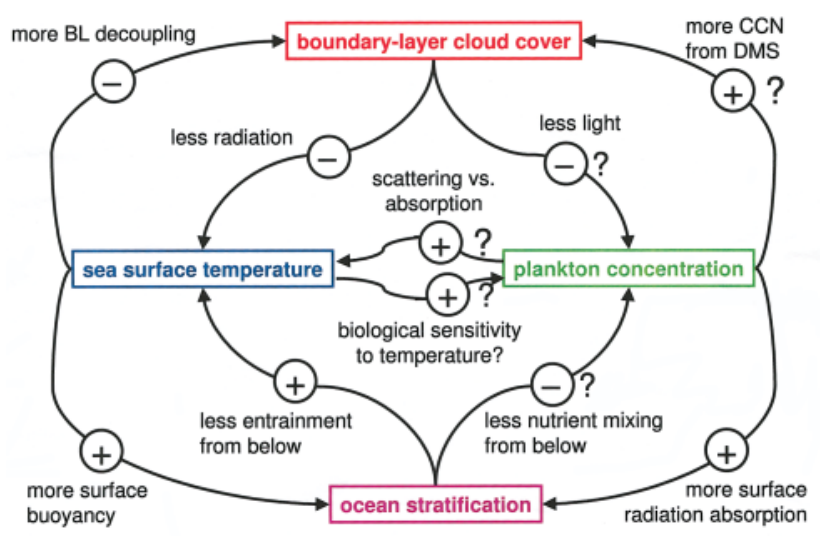

FIG. 8. Sketch of the various aspects of biological-physical interaction discussed in this paper. Arrows indicate the direction of forcing among boundary layer cloud cover, SST, ocean stratification, and plankton concentration. The sign indicates whether an increase in the forcing parameter causes an increase $(+)$ or decrease $(-)$ in the forced parameter. Here (?) indicates those processes that especially need more investigation.

processes significantly influence climate variability. We concentrated our attention on the Pacific Ocean ecosystem, but the concepts can be extended globally.

ACKNOWLEDGMENTS. This synthesis was conceived during the Surfside Climate Workshop on "Climate Forcing of Oceanic Ecosystems: Are Significant Biological Feedbacks Possible on Interdecadal Timescales?" held 1820 April 2001 in La Jolla, California. We are grateful to the director of the Scripps Institution of Oceanography for generous workshop funding, as well as to NSF (OCE00-82543) and NASA (NAG5-9788) for additional funding. The workshop theme was identified during an earlier International GLOBEC-sponsored workshop on "Marine Ecosystem and Climate Interactions in the Past, Present, and Future."

\section{REFERENCES}

Alexander, M. A., C. Deser, and M. S. Timlin, 1999: The reemergence of SST anomalies in the North Pacific Ocean. J. Climate, 12, 2419-2433.

— J. D. Scott, and C. Deser, 2000: Processes that influence sea surface temperature and ocean mixed layer depth variability in a coupled model. J. Geophys. Res., 105, 16 823-16 842.

—, M. S. Timlin, and J. D. Scott, 2001: Winter-to-winter recurrence of sea surface temperature, salinity and mixed layer depth anomalies. Progress in Oceanography, Vol. 49, Pergamon, 41-61.

—, I. Bladé, M. Newman, J. R. Lanzante, N.-C. Lau, and J. D. Scott, 2002: The atmospheric bridge: The influ- ence of ENSO teleconnections on air-sea interaction over the global oceans. J. Climate, 15, 2205-2231.

Andreae, M. O., and P. J. Crutzen, 1997: Atmospheric aerosols: Biogeochemical sources and role in atmospheric chemistry. Science, 276, 1052-1058.

Ayers, G. P., J. P. Ivey, and R. W. Gillett, 1991: Coherence between seasonal cycles of dimethylsulfide, methanesulphonate and sulphate in marine air. $\mathrm{Na}$ ture, 349, 404-406.

Barsugli, J. J., and D. S. Battisti, 1998: The basic effects of atmosphere-ocean thermal coupling on midlatitude variability. J. Atmos. Sci., 55, 477-493.

Bates, T. S., and P. K. Quinn, 1997: Dimethylsulfide (DMS) in the equatorial Pacific Ocean (1982 to 1996): Evidence of a climate feedback? Geophys. Res. Lett., 24, 861-864.

Baumgartner, T. R., A. Soutar, and V. Ferreira-Bartrina, 1992: Reconstruction of the history of Pacific sardine and northern anchovy populations over the past 2 millennia from sediments of the Santa-Barbara Basin, California. Calif Coop. Ocean. Fish. Invest. Rep., 33, 24-40.

Boers, R., G. P. Ayers, and J. L. Gras, 1994: Coherence between seasonal variation in satellite-derived cloud optical depth and boundary-layer CCN concentrations at a midlatitude Southern Hemisphere station. Tellus, 46, 123-131.

Chai, F., R. C. Dugdale, T.-H. Peng, F. P. Wilkerson, and R. T. Barber, 2002a: One dimensional ecosystem model of the equatorial Pacific upwelling system. Part I: Model development and silicon and nitrogen cycle. Deep-Sea Res., 49, 2713-2745.

—, M. Jiang, R. T. Barber, R. C. Dugdale, and Y. Chao, 2002b: Decadal variation of the transition zone chlorophyll front: A physical-biological model simulation between 1960 and 1990. J. Oceanogr., in press.

Chang, P., 1996: Chaotic dynamics versus stochastic process in El Niño-Southern Oscillation in coupled ocean-atmosphere models. Physica D, 98, 301-320.

Charlson, R. J., J. E. Lovelock, M. O. Andreae, and S. G. Warren, 1987: Oceanic phytoplankton, atmospheric sulphur, cloud albedo and climate. Nature, 326, 655661.

Chin, M., and D. D. Davis, 1995: A reanalysis of carbonyl sulfide as a source of stratospheric background sulfur aerosols. J. Geophys. Res., 100, 8993-9005.

— contributions to tropospheric sulfate: A global model analysis. J. Geophys. Res., 101, 18 691-18 699.

Cox, P. M., R. A. Betts, C. D. Jones, S. A. Spall, and I. J. Totterdell, 2000: Acceleration of global warming due to carbon-cycle feedbacks in a coupled climate model. Nature, 408, 184-187. 
Cropp, R., and A. Gabric, 2002: Ecosystem adaptation: Do ecosystems maximize resilience? Ecology, 83, 2019-2026.

Denman, K., E. E. Hofmann, and H. Marchant, 1996: Marine biotic responses to environmental change and feedbacks to climate. Climate Change 1995: The Science of Climate Change, J. T. Houghton et al., Eds., Cambridge University Press, 483-516.

Deser, C., and M. Blackmon, 1995: On the relationship between tropical and North Pacific sea surface temperature variations. J. Climate, 8, 1677-1680.

—, M. A. Alexander, and M. S. Timlin, 1996: Upperocean thermal variations in the North Pacific during 1970-1991. J. Climate, 9, 1840-1855.

Eppley, R. W., and B. J. Peterson, 1979: Particulate organic-matter flux and planktonic new production in the deep ocean. Nature, 282, 677-680.

Erickson, D. J., III, S. Ghan, and J. Penner, 1990: Global ocean to atmosphere dimethyl sulfide flux. J. Geophys. Res., 95, 7543-7552.

Field, D. B., and T. R. Baumgartner, 2000: A 900year stable isotope record of interdecadal and centennial change from the California Current. Paleooceanography, 15, 695-708.

Foley, J. A., K. E. Taylor, and S. J. Ghan, 1991: Planktonic dimethylsulfide and cloud albedo-An estimate of the feedback response. Climatic Change, 18, 1-15.

Francis, R. C., and S. R. Hare, 1994: Decadal scale regime shifts in the large marine ecosystems of the northeast Pacific: A case for historical science. Fish. Oceanogr., 3, 279-291.

,,-- A. B. Hollowed, and W. S. Wooster, 1998: Effects of interdecadal climate variability on the oceanic ecosystems of the NE Pacific. Fish. Oceanogr., 7, 1-21.

Frankignoul, C., P. Müller, and E. Zorita, 1997: A simple model of the decadal response of the ocean to stochastic wind forcing. J. Phys. Oceanogr., 27, 1533-1546.

Frouin, R., and S. F. Iacobellis, 2002: Influence of phytoplankton on the global radiation budget. J. Geophys. Res., 107 (D19), 5-1-5-10.

Gabric, A. J., P. H. Whetton, R. Boers, and G. P. T. Ayers, 1998: The impact of simulated climate change on the air-sea flux of dimethylsulphide in the subantarctic Southern Ocean. Tellus, 50, 388-399.

— - _ and R. Cropp, 2001: Dimethylsulphide production in the subantarctic Southern Ocean under enhanced greenhouse conditions. Tellus, 53, 273287.

Gattuso, J. P., M. Frankignoulle, I. Bourge, S. Romaine, and R. W. Buddemeier, 1998: Effect of calcium carbonate saturation of seawater on coral calcification. Global Planet. Change, 18, 37-46.
Goldman, J. C., 1980: Physiological processes, nutrient availability, and the concept of relative growth rate in marine phytoplankton ecology. Primary Productivity in the Sea, P. G. Falkowski, Ed., Plenum, 179194.

Gu, D. F., and S. G. H. Philander, 1997: Interdecadal climate fluctuations that depend on exchanges between the tropics and extratropics. Science, 275, 805-807.

Guilderson, T. P., and D. P. Schrag, 1998: Abrupt shift in subsurface temperatures in the tropical Pacific associated with changes in El Niño. Science, 281, 240243.

Haigh, S. P., K. L. Denman, and W. W. Hsieh, 2001: Simulation of the planktonic ecosystem response to pre- and post-1976 forcing in an isopycnic model of the North Pacific. Can. J. Fish. Aquat. Sci., 58, 703-722.

Hasselmann, K., 1976: Stochastic climate models. Part I. Theory. Tellus, 28, 473-485.

Hutchinson, G. E., 1967: A Treatise on Limnology. Vol II. Wiley, 1115 pp.

Houghton, J. T., Y. Ding, D. J. Griggs, M. Noguer, P. J. van der Linden, and D. Xiaosu, Eds., 2001: Climate Change 2001: The Scientific Basis. Contribution of Working Group I to the Third Assessment Report of the Intergovernmental Panel on Climate Change. Cambridge University Press, 944 pp.

Jin, F.-F., 2001: Low-frequency modes of tropical ocean dynamics. J. Climate, 14, 3874-3881.

_, J. D. Neelin, and M. Ghil, 1994: El Niño on the devil's staircase: Annual subharmonic steps to chaos. Science, 264, 70-72.

Jorgensen, S. E., 2000: A general outline of thermodynamic approaches to ecosystem theory. Handbook of Ecosystem Theories and Management, S. E. Jorgensen and F. Muller, Eds., CRC Press, 113-123.

—- and M. Straskraba, 2000: Ecosystems as cybernetic systems. Handbook of Ecosystem Theories and Management, S. E. Jorgensen and F. Muller, Eds., CRC Press, 249-260.

Kiehl, J. T., and B. P. Briegleb, 1993: The relative roles of sulfate aerosols and greenhouse gases in climate forcing. Science, 260, 311-314.

Kleeman, R., J. P. McCreary, and B. A. Klinger, 1999: A mechanism for the decadal variation of ENSO. Geophys. Res. Lett., 26, 1743-1746.

Kleypas, J. A., R. W. Buddemeier, D. Archer, J.-P. Gattuso, C. Langdon, and B. N. Opdyke, 1999: Geochemical consequences of increased atmospheric carbon dioxide on coral reefs. Science, 284, 118-120.

Latif, M., 1998: Dynamics of interdecadal variability in coupled ocean-atmosphere models. J. Climate, 11, 602-624. 
_ , and T. P. Barnett, 1994: Causes of decadal climate variability over the North Pacific and North America. Science, 266, 634-637.

Lau, N. C., and M. J. Nath, 1996: The role of the "atmospheric bridge" in linking tropical Pacific ENSO events to extratropical SST anomalies. J. Climate, 9 , 2036-2057.

Lawrence, M. G., 1993: An empirical-analysis of the strength of the phytoplankton-dimethylsulfidecloud-climate feedback cycle. J. Geophys. Res., 98, $20663-20673$.

Laws, E. A., P. G. Falkowski, W. O. Smith, H. Ducklow, and J. J. McCarthy, 2000: Temperature effects on export production in the open ocean. Global Biogeochem. Cycl., 14, 1231-1246.

Leclercq, N., J. Gattuso, and J. Jaubert, 2000: $\mathrm{CO}_{2}$ partial pressure controls the calcification rate of a coral community. Global Change Biol., 6, 329-334.

Legrand, M., and C. Feniet-Saigne, 1991: Methanesulfonic acid in south polar snow layers: A record of strong El Niño. Geophys. Res. Lett., 18, 187190.

Limsakul, A., T. Saino, T. Midorikawa, and J. I. Goes, 2001: Temporal variations in lower trophic level biological environments in the northwestern North Pacific subtropical gyre from 1950 to 1997. Progress in Oceanography, Vol. 49, Pergamon, 129149.

Liu, Z. Y., and S. I. Shin, 1999: On thermocline ventilation of active and passive tracers. Geophys. Res. Lett., 26, 357-360.

— , L. Wu, R. Gallimore, and R. Jacob, 2002: Search for the origins of Pacific decadal climate variability. Geophys. Res. Lett., 29, 1404, doi:10.1029/ $2001 \mathrm{GL} 013735$.

Lotka, A. J., 1922: Contribution to the energetics of evolution. Proc. Natl. Acad. Sci., 8, 147-150.

Mackas, D. L., R. Goldblatt, and A. G. Lewis, 1998: Interdecadal variation in developmental timing of Neocalanus plumchrus populations at Ocean Station $\mathrm{P}$ in the subarctic North Pacific. Can. J. Fish. Aquat. Sci., 55, 1878-1893.

Maier-Reimer, E., U. Mikolajewicz, and A. Winguth, 1996: Future ocean uptake of $\mathrm{CO}_{2}$ : Interaction between ocean circulation and biology. Climate Dyn., 12, 711-722.

Mantua, N. J., S. R. Hare, Y. Zhang, J. M. Wallace, and R. C. Francis, 1997: A Pacific interdecadal climate oscillation with impacts on salmon production. Bull. Amer. Meteor. Soc., 78, 1069-1079.

Matear, R. J., and A. C. Hirst, 1999: Climate change feedback on the future oceanic $\mathrm{CO}_{2}$ uptake. Tellus, 51, $722-733$.
McGowan, J. A., D. R. Cayan, and L. M. Dorman, 1998: Climate-ocean variability and ecosystem response in the northeast Pacific. Science, 281, 210-217.

McPhaden, M. J., and D. X. Zhang, 2002: Decadal spindown of the Pacific ocean shallow meridional overturning circulation. Nature, 415, 603-608.

Miller, A. J., and N. Schneider, 2000: Interdecadal climate regime dynamics in the North Pacific Ocean: Theories, observations and ecosystem impacts. Progress in Oceanography, Vol. 47, Pergamon, 355-379. —, D. R. Cayan, T. P. Barnett, N. E. Graham, and J. M. Oberhuber, 1994: The 1976-77 climate shift of the Pacific Ocean. Oceanography, 7, 21-26.

— - — , and W. B. White, 1998: A westward intensified decadal in the North Pacific thermocline and gyre-scale circulation. J. Climate, 11, 3112-3127.

Murray, J. W., R. T. Barber, M. R. Roman, M. P. Bacon, and R. A. Feely, 1994: Physical and biological controls on carbon cycling in the equatorial Pacific. Science, 266, 58-65.

Murtugudde, R., J. Ballabrera-Poy, J. Beauchamp, and A. Busalacchi, 2001: Relationship between the zonal and meridional modes in the tropical Atlantic. Geophys. Res. Lett., 28, 4463-4466.

—, J. Beauchamp, C. R. McClain, M. Lewis, and A. Busalacchi, 2002: Effects of penetrative radiation on the upper tropical ocean circulation. J. Climate, 15, 471-487.

Nakamoto, S., S. Prasanna Kumar, J. M. Oberhuber, K. Muneyama, and R. Frouin, 2000: Chlorophyll modulation of sea surface temperature in the Arabian Sea in a mixed layer isopycnal general circulation model. Geophys. Res. Lett., 27, 747-750.

,,--- , J. Ishizaka, K. Muneyama, and R. Frouin, 2001a: Response of the equatorial Pacific to chlorophyll pigments in a mixed layer isopycnal ocean general circulation model. Geophys. Res. Lett., 28, 2021-2024.

$\longrightarrow,-,-$ H. Saito, K. Muneyama, and R. Frouin, 2001b: Chlorophyll modulation of mixed layer dynamics in a mixed layer isopycnal general circulation model. Proc. Indian Acad. Sci. (Earth Planet. Sci.), 111, 339-349.

Nakamura, H., G. Lin, and T. Yamagata, 1997: Decadal climate variability in the North Pacific during recent decades. Bull. Amer. Meteor. Soc., 78, 2215-2225.

Nonaka, M., S.-P. Xie, and J. P. McCreary, 2002: Decadal variations in the subtropical cell and equatorial $\mathrm{Pa}$ cific SST. Geophys. Res. Lett., 29, 1116, 10.1029/ $2001 G L 013717$.

Norris, J. R., and C. B. Leovy, 1994: Interannual variability in stratiform cloudiness and sea-surface temperature. J. Climate, 7, 1915-1925. 
Odum, H. T., 1983: Systems Ecology: An Introduction. Wiley, 644 pp.

Ohlmann, J. C., D. A. Siegel, and L. Washburn, 1998: Radiant heating of the western equatorial Pacific during TOGA-COARE. J. Geophys. Res., 103, 53795395.

Peng, S. L., W. A. Robinson, and M. P. Hoerling, 1997: The modeled atmospheric response to midlatitude SST anomalies and its dependence on background circulation states. J. Climate, 10, 971-987.

Polovina, J., G. T. Mitchum, N. E. Graham, M. P. Craig, E. E. DeMartini, and E. N. Flint, 1994: Physical and biological consequences of a climatic event in the Central North Pacific. Fish. Oceanogr., 3, 15-21.

Riebesell, U., I. Zondervan, B. Rost, P. D. Tortell, R. E. Zeebe, and F. M. M. Morel, 2000: Reduced calcification of marine plankton in response to increased atmospheric $\mathrm{CO}_{2}$. Nature, 407, 364-367.

Sarmiento, J. L., and S. C. Wofsy, Co-chairs, 1999: A U.S. carbon cycle science plan: A Report of the Carbon and Climate Working Group. U.S. Global Change Research Program, $69 \mathrm{pp}$.

— - T. M. C. Hughes, R. L. Stouffer, and S. Manabe, 1998: Simulated response of the ocean carbon cycle to anthropogenic climate warming. Nature, 393, 245-249.

—, A. D. Gouveia, S. R. Shetye, P. Ravindran, and T. Platt, 1991: Biological control of surface temperature in the Arabian Sea. Nature, 349, 54-56.

Schneider, E. K., and Z. Zhu, 1998: Sensitivity of the simulated annual cycle of the sea surface temperature in the equatorial Pacific to sunlight penetration. $J$. Climate, 11, 1932-1950.

Schneider, N., and A. J. Miller, 2001: Predicting western North Pacific Ocean climate. J. Climate, 14, 3997-4002.

_-, T. Barnett, M. Latif, and T. Stockdale, 1996: Warm pool physics in a coupled GCM. J. Climate, 9, 219239.

—_, A. J. Miller, M. A. Alexander, and C. Deser, 1999: Subduction of decadal North Pacific temperature anomalies: Observations and dynamics. J. Phys. Oceanogr., 29, 1056-1070.

,$- \ldots$, and D. W. Pierce, 2002: Anatomy of North Pacific decadal variability. J. Climate, 15, 586-605.

Schwartzlose, R. A., and Coauthors, 1999: Worldwide large-scale fluctuations of sardine and anchovy populations. S. Afr. J. Mar. Sci., 21, 289-347.

Shaw, G. E., 1983: Bio-controlled thermostasis involving the sulphur cycle. Climatic Change, 5, 297-303.

Shin, S., and Z. Liu, 2000: Response of equatorial thermocline to extratropical buoyancy forcing. J. Phys. Oceanogr., 30, 2883-2905.
Simo, R., 2001: Production of atmospheric sulfur by oceanic plankton: Biogeochemical, ecological and evolutionary links. Trends Ecol. Evol., 16, 287-294.

Sugimoto, T., and K. Tadokoro, 1997: Interannualinterdecadal variations in zooplankton biomass, chlorophyll concentration and physical environment in the subarctic Pacific and Bering Sea. Fish. Oceanogr., 6, 74-93.

Tanimoto, Y., K. Hanawa, Y. Toba, and N. Iwasaka, 1993: Characteristic variations of sea surface temperature with multiple time scales in the North $\mathrm{Pa}$ cific. J. Climate, 6, 1153-1160.

Timmermann, A., 2003: Decadal ENSO amplitude modulations: A nonlinear paradigm. Global Planet. Change, in press.

—, and F.-F. Jin, 2002: A nonlinear mechanism for decadal El Niño amplitude changes. Geophys. Res. Lett., 29, 1003, doi:10.1029/2001GL013369.

Tourre, Y., W. B. White, and Y. Kushnir, 1999: Evolution of interdecadal variability in sea level pressure, sea surface temperature, and upper ocean temperature over the Pacific Ocean. J. Phys. Oceanogr., 29, 1528-1541.

Trenberth, K. E., and T. J. Hoar, 1996: The 1990-1995 El Niño-Southern Oscillation event: Longest on record. Geophys. Res. Lett., 23, 57-60.

Tziperman, E., L. Stone, M. A. Cane, and H. Jarosh, 1994: El Niño chaos: Overlapping of resonances between the seasonal cycle and the Pacific Oceanatmosphere oscillator. Science, 264, 72-74.

Venrick, E. L., J. A. McGowan, D. R. Cayan, and T. L. Hayward, 1987: Climate and chlorophyll-a: Longterm trends in the central North Pacific Ocean. Science, 238, 70-72.

Wang, C. Z., and R. H. Weisberg, 1998: Climate variability of the coupled tropical-extratropical oceanatmosphere system. Geophys. Res. Lett., 25, 39793982.

Wanninkhof, R., 1992: Relationship between windspeed and gas-exchange over the ocean. J. Geophys. Res., 97, 7373-7382.

Ware, D. M., 1995: A century and a half of change in the climate of the NE Pacific. Fish. Oceanogr., 4, 267-277.

Watanabe, M., and M. Kimoto, 2000: On the persistence of decadal SST anomalies in the North Atlantic. J. Climate, 13, 3017-3028.

Whitney, F. A., C. S. Wong, and P. W. Boyd, 1998: Interannual variability in nitrate supply to surface waters of the northeast Pacific Ocean. Mar. Ecol. Prog. Ser., 170, 15-23.

Zhang, Y., J. M. Wallace, and D. S. Battisti, 1997: ENSOlike interdecadal variability: 1900-93. J. Climate, 10, 1004-1020. 